\title{
Florida Dairy Industry Statistics: Economic Measures ${ }^{1}$
}

\author{
K.G. Arriola and A. De Vries ${ }^{2}$
}

This publication brings together key economic and price data about Florida's primary dairy industry collected by the U.S. Department of Agriculture (USDA). These data are published on various websites by the USDA and others, but can be difficult to locate.

Table 1 shows the number of dairy herds and cows, and the amount of milk production per year from 2004 to 2012, as well as cash receipts from milk marketing. The 2012 Florida Annual Statistical Bulletin (available at http://www.nass.usda.gov/fl) reported that Florida dairy producers produced 2.27 billion pounds of milk in 2011, and annual milk production per cow was 19,067 pounds. Licensed dairy herds (dairy farms licensed by the Florida Department of Agriculture and Consumer Services to sell milk) decreased from 190 in 2006 to 140 in 2007 and have remained constant since.

The number of milk cows decreased from 136,000 in 2004 to 114,000 in 2010 but increased about $8 \%$ in the last two years. Milk production per cow per year increased from 16,326 pounds in 2004 to 19,067 pounds in 2011. Total milk production in Florida decreased from 2,253 million pounds in 2004 to 2,060 million pounds in 2008 but increased again to 2,269 million pounds in 2011. On farm nominal (not inflation adjusted) cash receipts from marketing (selling milk) increased from $\$ 344$ million in 2006 to $\$ 545$ million in 2011 (throughout this report all monetary amounts are reported in nominal dollars, not inflation-adjusted real dollars). The annual fluctuation in total cash receipts is primarily the result of fluctuations in the price of milk that farmers receive.

Figure 1 shows milk production and number of milking cows since 1960 in Florida. Milk production includes milk produced for sale on the farm, but milk fed to calves is excluded. By USDA's definition, milk cows are cows raised for the purpose of milk production and include all cows and heifers after calving. The number of milk cows on Florida farms decreased from 194,000 head in 1960 to 123,000 head in 2012 (based on January through December estimates) but has increased slightly in the last two years. Milk production per cow in Florida has increased more than $180 \%$ since 1960 . Milk production per cow was 6,725 lbs/year in 1960 compared to 19,055 lbs/year in 2012 (based on January through December estimates).

Figure 2 shows milk production since 1960 in Florida. Milk production includes milk produced for sale on the farm. Although the number of milk cows on the farm (Figure 1) decreased by more than $30 \%$, total milk production increased more than $60 \%$ from 1960 to 2012. In 1960, 1,306 million pounds were produced compared to 2,334 million pounds produced in 2012 (based on January through December estimates).

Table 2 shows milk production cost and returns per hundredweight (cwt $=100$ pounds) and milk sold from farms in Florida from 2005 to 2011. USDA collects these data through interviews and cost price adjustments. Data used to produce milk cost estimates include annual and monthly

1. This document is AN287, one of a series of the Department of Animal Sciences, Florida Cooperative Extension Service, Institute of Food and Agricultural Sciences, University of Florida. Original publication date February 2013. Visit the EDIS website at http://edis.ifas.ufl.edu.

2. K.G. Arriola, post-doctoral research associate, Department of Animal Sciences; and A. De Vries, associate professor, Department of Animal Sciences; Florida Cooperative Extension Service, Institute of Food and Agricultural Sciences, University of Florida, Gainesville, FL 32611. 


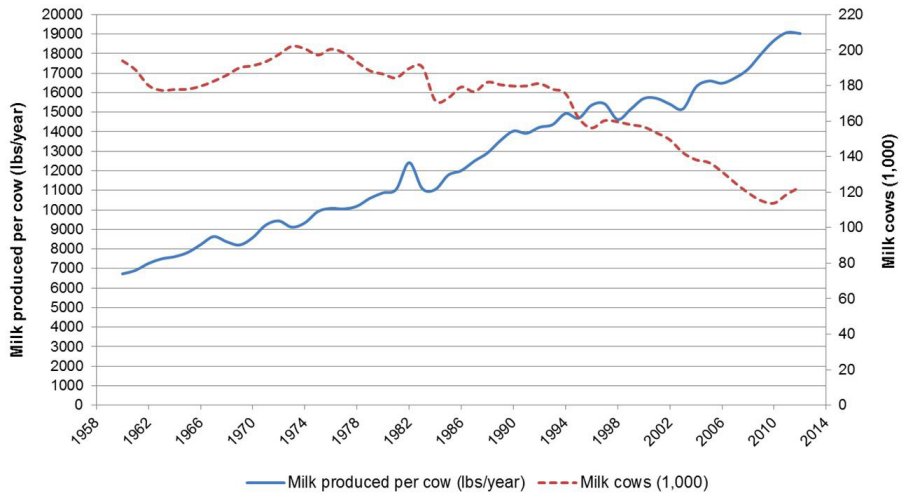

Figure 1. Milk produced per cow and milk cows on farm in Florida from 1960 to 2012. Milk cows are cows raised for the purpose of milk production and include all cows and heifers after calving. Milk production includes milk produced for sale, but milk fed to calves is excluded. Source: Brian W. Gould, University of Wisconsin Department of Agricultural and Applied Economics, Dairy Marketing and Risk Management Program, accessed January 2013, http://future.aae.wisc. edu.

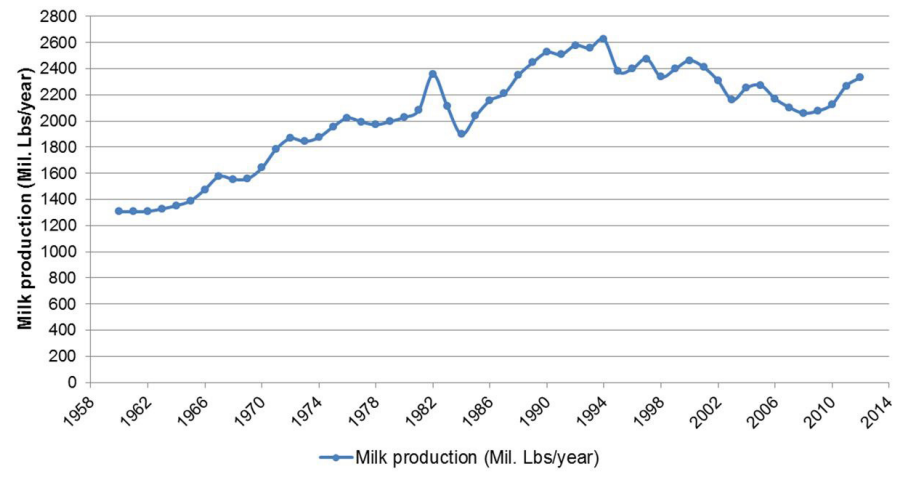

Figure 2. Milk production in Florida from 1960 to 2012. Milk production includes milk produced for sale, but milk fed to calves is excluded. Source: Brian W. Gould, University of Wisconsin Department of Agricultural and Applied Economics, Dairy Marketing and Risk Management Program, accessed January 2013, http://future.aae.wisc. edu.

Table 1. Number of dairy herds and dairy cows in Florida, as well as the amount of milk produced and total cash receipts from milk marketing (2004-2012).

\begin{tabular}{|c|c|c|c|c|c|}
\hline Year & $\begin{array}{l}\text { Number of milk } \\
\text { cows }^{1} \\
(1,000)\end{array}$ & $\begin{array}{l}\text { Milk production } \\
\text { per cow } \\
\text { (Ibs/year) }\end{array}$ & $\begin{array}{l}\text { Milk production } \\
\text { (million lbs) }\end{array}$ & $\begin{array}{l}\text { Cash receipts from } \\
\text { marketing } \\
(\$ 1,000)\end{array}$ & $\begin{array}{c}\text { Number of licensed } \\
\text { dairy herds }\end{array}$ \\
\hline 2004 & 136 & 16,326 & 2,253 & 431,616 & 190 \\
\hline 2005 & 137 & 16,577 & 2,273 & 421,662 & 180 \\
\hline 2006 & 132 & 16,417 & 2,171 & 344,235 & 160 \\
\hline 2007 & 127 & 16,832 & 2,104 & 459,243 & 140 \\
\hline 2008 & 115 & 17,167 & 2,060 & 464,204 & 140 \\
\hline 2009 & 119 & 18,070 & 2,077 & 350,168 & 140 \\
\hline 2010 & 114 & 18,658 & 2,127 & 439,047 & 140 \\
\hline 2011 & 119 & 19,067 & 2,269 & 545,383 & 140 \\
\hline $2012^{2}$ & 123 & 19,055 & 2,334 & $N / A^{*}$ & $\mathrm{~N} / \mathrm{A}$ \\
\hline \multicolumn{6}{|c|}{$\begin{array}{l}{ }^{1} \text { Average monthly values during year, excluding heifers not yet fresh. } \\
{ }^{2} \text { Average of January through December } 2012 \text {, excluding heifers not yet fresh. } \\
{ }^{*} \text { N/A = not available } \\
\text { Source: USDA Agricultural Marketing Service Dairy Programs, accessed January }\end{array}$} \\
\hline
\end{tabular}

prices paid for selected farm inputs, services, supplies, and repairs, interest, wage rates, rent, and taxes. Major trends include changes in the value of milk sold as a result of the price paid to dairy farmers and recent large increases in feed cost and allocated overhead. The value of production less total costs, which is similar to profit per cwt milk sold, was lowest in 2009 at a loss of $\$ 5.87 /$ cwt and highest in 2007 at a positive $\$ 2.30 /$ cwt.

The annual average Florida milk price (\$/cwt) since 1960 is shown in Figure 3. The "all milk" prices include milk prices from all four Federal Milk Marketing Order (FMMO) Classes (Class I, II, III, and IV). The FMMO establishes minimum class prices for the four classes of milk products each month. Class I is Grade A milk used in all beverage milks; Class II is Grade A milk used in fluid cream products, yogurts, or perishable manufactured products (ice cream, cottage cheese, and others); Class III is Grade A milk used to produce cream cheese and hard manufactured cheese; Class IV is Grade A milk used to produce butter and any milk in dried form.

The "all" milk price was fairly stable from the early 1960s until the early 1970s. Prices from the 1960s (\$6.66/cwt) were doubled in the late 1970s (\$12.34/cwt). The "all" milk price increased more than $200 \%$ during the last 50 years (the reported milk price was $\$ 6.71 / \mathrm{cwt}$ in 1960 compared to $\$ 22.36 /$ cwt in 2012).

Table 3 compares the average mailbox prices (net price to dairy farmers at the farm gate) in Florida and the FMMO whole milk retail price for Miami, Florida from 1997 to 2012. Mailbox prices include all payments received for milk sold and all deductions for costs associated with marketing 


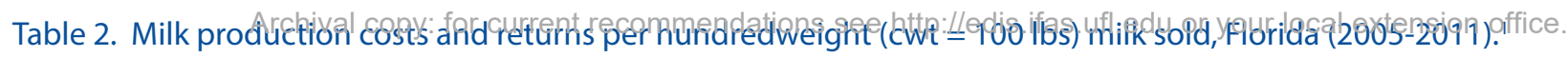

\begin{tabular}{|c|c|c|c|c|c|c|c|}
\hline Item & 2005 & 2006 & 2007 & 2008 & 2009 & 2010 & 2011 \\
\hline \multicolumn{8}{|l|}{ Gross value of production: } \\
\hline Milk sold & 18.00 & 15.39 & 21.20 & 21.87 & 16.29 & 20.48 & 23.84 \\
\hline Cattle & 1.08 & 1.00 & 1.04 & 1.12 & 0.94 & 1.35 & 1.76 \\
\hline Other income ${ }^{2}$ & 0.56 & 0.60 & 0.75 & 1.34 & 0.94 & 0.92 & 1.20 \\
\hline Total, gross value of production & 19.64 & 16.99 & 22.99 & 24.33 & 18.17 & 22.75 & 26.80 \\
\hline \multicolumn{8}{|l|}{ Operating costs: } \\
\hline \multicolumn{8}{|l|}{ Feed } \\
\hline Purchased feed & 7.22 & 7.07 & 7.82 & 10.38 & 11.28 & 9.56 & 11.12 \\
\hline Homegrown harvested feed & 1.72 & 1.77 & 2.04 & 2.38 & 1.48 & 2.06 & 2.39 \\
\hline Grazed feed & 0.12 & 0.14 & 0.15 & 0.15 & 0.11 & 0.07 & 0.06 \\
\hline Total, feed costs & 9.06 & 8.98 & 10.01 & 12.91 & 12.87 & 11.69 & 13.57 \\
\hline \multicolumn{8}{|l|}{ Other } \\
\hline Veterinary and medicine & 0.79 & 0.83 & 0.86 & 0.87 & 0.95 & 0.57 & 0.58 \\
\hline Bedding and litter & 0.03 & 0.03 & 0.03 & 0.03 & 0.03 & 0.01 & 0.01 \\
\hline Marketing & 0.18 & 0.19 & 0.19 & 0.20 & 0.21 & 0.15 & 0.15 \\
\hline Custom services & 0.72 & 0.75 & 0.78 & 0.78 & 0.85 & 0.48 & 0.49 \\
\hline Fuel, lube, and electricity & 0.70 & 0.78 & 0.86 & 1.12 & 0.74 & 0.81 & 1.03 \\
\hline Repairs & 0.73 & 0.78 & 0.80 & 0.87 & 0.89 & 0.53 & 0.55 \\
\hline Other operating costs ${ }^{3}$ & 0.00 & 0.00 & 0.00 & 0.00 & 0.00 & 0.00 & 0.00 \\
\hline Interest on operating capital & 0.21 & 0.29 & 0.30 & 0.15 & 0.02 & 0.01 & 0.01 \\
\hline Total, operating cost & 12.42 & 12.63 & 13.83 & 16.93 & 16.56 & 14.25 & 16.39 \\
\hline \multicolumn{8}{|l|}{ Allocated overhead: } \\
\hline Hired labor & 3.05 & 3.03 & 3.14 & 3.26 & 3.38 & 2.46 & 2.52 \\
\hline Opportunity cost of unpaid labor & 0.42 & 0.44 & 0.48 & 0.52 & 0.56 & 0.58 & 0.55 \\
\hline $\begin{array}{l}\text { Capital recovery of machinery and } \\
\text { equipment }{ }^{4}\end{array}$ & 2.21 & 2.35 & 2.43 & 2.62 & 2.68 & 4.48 & 4.70 \\
\hline Opportunity cost of land (rental rate) & 0.02 & 0.03 & 0.03 & 0.03 & 0.02 & 0.02 & 0.02 \\
\hline Taxes and insurance & 0.24 & 0.25 & 0.26 & 0.26 & 0.29 & 0.15 & 0.15 \\
\hline General farm overhead & 0.48 & 0.50 & 0.52 & 0.53 & 0.55 & 0.51 & 0.53 \\
\hline Total, allocated overhead & 6.42 & 6.60 & 6.86 & 7.22 & 7.48 & 8.20 & 8.47 \\
\hline Total costs listed & 18.84 & 19.23 & 20.69 & 24.15 & 24.04 & 22.45 & 24.86 \\
\hline Value of production less total costs listed & 0.80 & -2.24 & 2.30 & 0.18 & -5.87 & 0.30 & 1.94 \\
\hline Value of production less operating costs & 7.22 & 4.36 & 9.16 & 7.40 & 1.61 & 8.50 & 10.41 \\
\hline \multicolumn{8}{|l|}{ Supporting information: } \\
\hline Milk cows (head per farm) & 1,013 & 1,015 & 1,017 & 1,054 & 1,059 & 905 & 927 \\
\hline Output per cow (lbs/year) & 17,572 & 17,576 & 17,581 & 17,609 & 17,613 & 18,071 & 18,110 \\
\hline $\begin{array}{l}\text { Milking frequency more than twice per } \\
\text { day (percent of farms) }\end{array}$ & 36.16 & 36.05 & 35.93 & 37.01 & 37.13 & 17.10 & 17.69 \\
\hline $\begin{array}{l}\text { Milk cows injected with bST (head per } \\
\text { farm) }\end{array}$ & 167 & 168 & 169 & 178 & 180 & 0.00 & 0.00 \\
\hline Organic milk sold (percent of sales) & 0.00 & 0.00 & 0.00 & 0.00 & 0.00 & 0.00 & 0.00 \\
\hline \multicolumn{8}{|c|}{$\begin{array}{l}{ }^{1} \text { Developed from the } 2005 \text { Agricultural Resource Management Survey of dairy operations using each year's price (2 } \\
\text { base year } 2010 \text { ( } 2010 \text { and } 2011) \text {. } \\
{ }^{2} \text { Income from renting or leasing dairy stock to other operations; renting space to other dairy operations; co-op pat } \\
\text { associated with the dairy; assessments rebates, refunds, and other dairy-related resources; and the fertilizer value } 0 \\
{ }^{3} \text { Cost of third-party organic certification. } \\
{ }^{4} \text { Machinery and equipment, housing, manure handling, feed storage structures, and the dairy breeding herd. } \\
\text { Source: USDA Economic Resource Service (ERS), accessed January 2013, http://www.ers.usda.gov/. }\end{array}$} \\
\hline
\end{tabular}




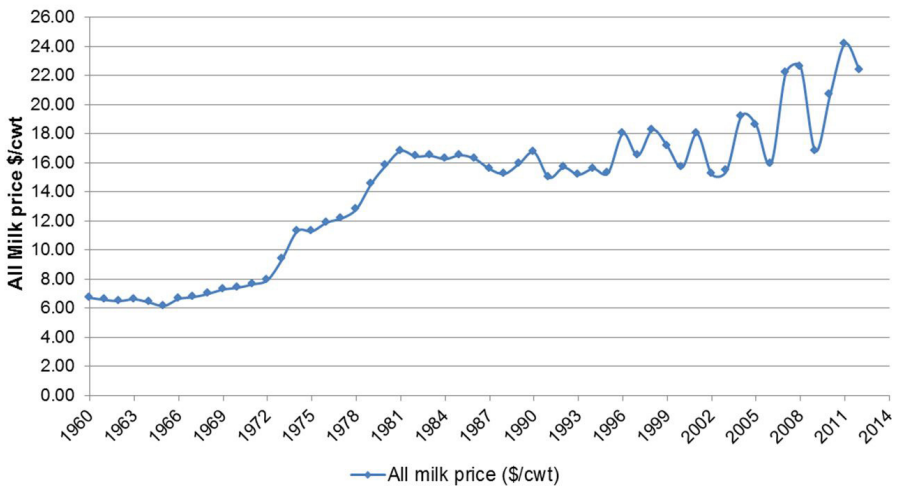

Figure 3. "All" milk price (\$/cwt) from 1960 to 2012 for milk produced on farm in Florida. The "all milk" price is the average price for milk used for all four FMMO Classes. Source: Brian W. Gould, University of Wisconsin Department of Agricultural and Applied Economics, Dairy Marketing and Risk Management Program, accessed January 2013, http://future.aae.wisc.edu/.

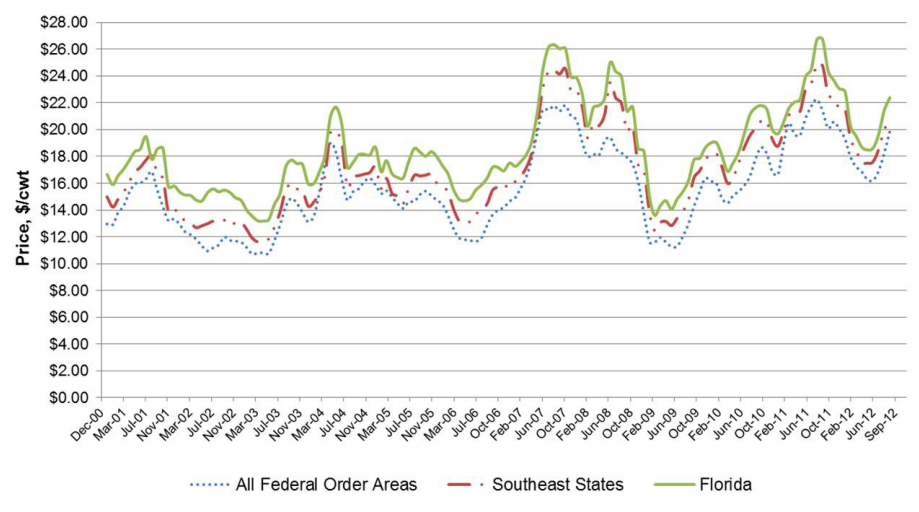

Figure 4. Mailbox milk prices for all FMMO areas, Southeast, and Florida. The All FMMO area includes Pacific Northwest, Arizona, Southwest, Central, Upper Midwest, Southeast, Mideast, Florida, Appalachian, and Northeast. Source: USDA Agricultural Marketing Service Dairy Programs, accessed January 2013, http://www. fmmatlanta.com.

Table 3. Florida mailbox prices ${ }^{1}$ and FMMO whole milk retail price ${ }^{2}$ for Miami, Florida (1997-2012).

\begin{tabular}{|c|c|c|c|c|}
\hline \multicolumn{3}{|c|}{ Florida mailbox prices } & \multicolumn{2}{|c|}{ Miami whole milk retail price } \\
\hline Year & \$/cwt & \$/gallon & $\$ / c w t$ & \$/gallon \\
\hline 1997 & 15.89 & 1.37 & 34.39 & 2.96 \\
\hline 1998 & 17.50 & 1.51 & 34.65 & 2.98 \\
\hline 1999 & 17.32 & 1.49 & 35.49 & 3.05 \\
\hline 2000 & 15.76 & 1.36 & 35.19 & 3.03 \\
\hline 2001 & 17.69 & 1.52 & 36.27 & 3.12 \\
\hline 2002 & 15.23 & 1.31 & 34.99 & 3.01 \\
\hline 2003 & 14.88 & 1.28 & 36.57 & 3.15 \\
\hline 2004 & 18.26 & 1.57 & 38.89 & 3.34 \\
\hline 2005 & 17.64 & 1.52 & 39.61 & 3.41 \\
\hline 2006 & 16.08 & 1.38 & 38.75 & 3.33 \\
\hline 2007 & 21.98 & 1.89 & 45.20 & 3.89 \\
\hline 2008 & 22.50 & 1.94 & 48.98 & 4.21 \\
\hline 2009 & 15.89 & 1.37 & 38.32 & 3.30 \\
\hline 2010 & 19.55 & 1.68 & 40.59 & 3.49 \\
\hline 2011 & 23.32 & 2.01 & 44.62 & 3.84 \\
\hline $2012^{3}$ & 20.57 & 1.77 & 44.49 & 3.83 \\
\hline \multicolumn{5}{|c|}{$\begin{array}{l}{ }^{1} \text { Mailbox prices are the net prices received by dairy farmers at their farm gate in their mailboxes. It includes all payment received for milk sold } \\
\text { and all deductions for costs associated with marketing the milk (USDA Agricultural Marketing Services). } \\
{ }^{2} \text { Federal Milk Marketing Orders (FMMO) released whole milk retail price by major city (e.g., Miami) based on a survey. } \\
{ }^{3} \text { Estimates for mailbox price based on January through October estimates. Estimates for retail price based on January through May estimates. } \\
\text { Source: Brian W. Gould, University of Wisconsin Department of Agricultural and Applied Economics, Dairy Marketing and Risk Management } \\
\text { Program, accessed January 2013, http://future.aae.wisc.edu. }\end{array}$} \\
\hline
\end{tabular}




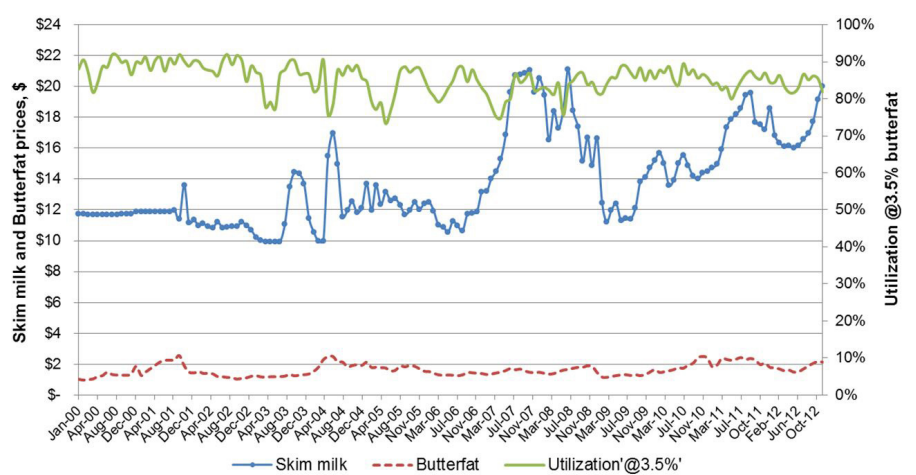

Figure 5. Federal Milk Marketing Order 6 (Florida) Class I prices and utilization at 3.5\% butterfat. Source: USDA Agricultural Marketing Service Dairy Programs, accessed January 2013, http://www. fmmatlanta.com.

the milk to the milk buyer. Average mailbox prices are collected by USDA survey. The FMMO administration releases whole milk retail price by major city (for example, Miami) based on a survey conducted twice every month. Florida mailbox prices followed the trends of the "all" milk price, including larger swings since 2007 . Whole milk retail prices in Miami were mostly stable from 1997 to 2006 but have varied more recently. On average, Florida mailbox prices were $46 \%$ of the whole milk retail prices for Miami with variations between $41 \%$ in 2003 and 51\% in 1998 .

Mailbox milk prices for all FMMO areas (All), FMMO 7 (Southeast), and FMMO 6 (Florida) are reported monthly from 2001 to September 2012 in Figure 4. The All FMMO area includes most of the monthly producer milk pooled from 33 states in 10 FMMOs (Pacific Northwest, Arizona, Southwest, Central, Upper Midwest, Southeast, Mideast, Florida, Appalachian, and Northeast). The mailbox milk price for All FMMO areas does not include all or parts of the following 17 states: Alaska, Arizona, California, Colorado, Delaware, Hawaii, Idaho, Maryland, Montana, Nevada, New Jersey, North Dakota, Oklahoma, South Dakota, Utah, West Virginia, and Wyoming. Since 2001, prices for All FMMO areas, including the Southeast and Florida, were the highest in 2007 and 2008. The prices sharply decreased in 2009 but increased again in 2010. Because of the high Class I utilization in Florida, the Florida mailbox price is typically higher than the Southeast price and the All FMMO price.

Historical FMMO 6 (Florida) prices and utilization at 3.5\% butterfat (for all classes in Florida) have been reported monthly from January 2000 to December 2012. Dairy farmers in FMMO 6 get paid for skim milk and butterfat but not for milk protein. Uniform skim milk and butterfat prices are the average values of each of the four classes of skim milk and butterfat prices weighed by utilization.

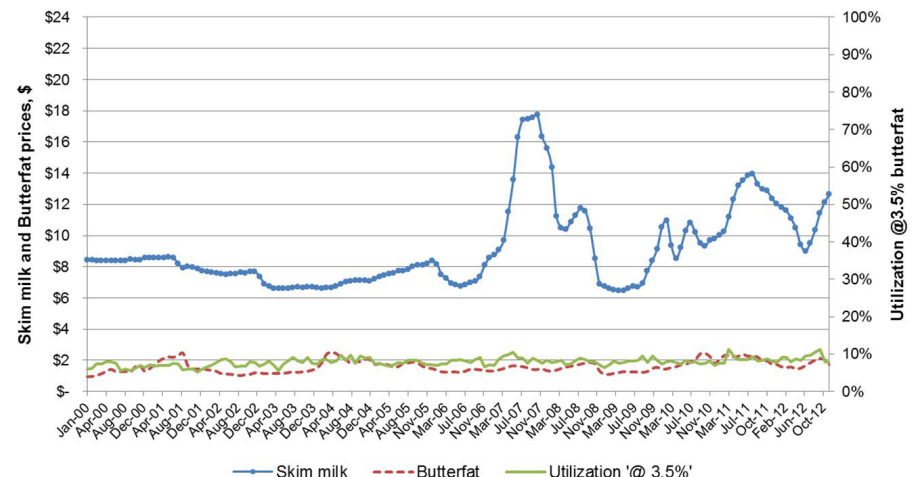

Figure 6. Federal Milk Marketing Order 6 (Florida) Class II prices and utilization at 3.5\% butterfat. Source: USDA Agricultural Marketing Service Dairy Programs, accessed January 2013, http://fmmatlanta. com.

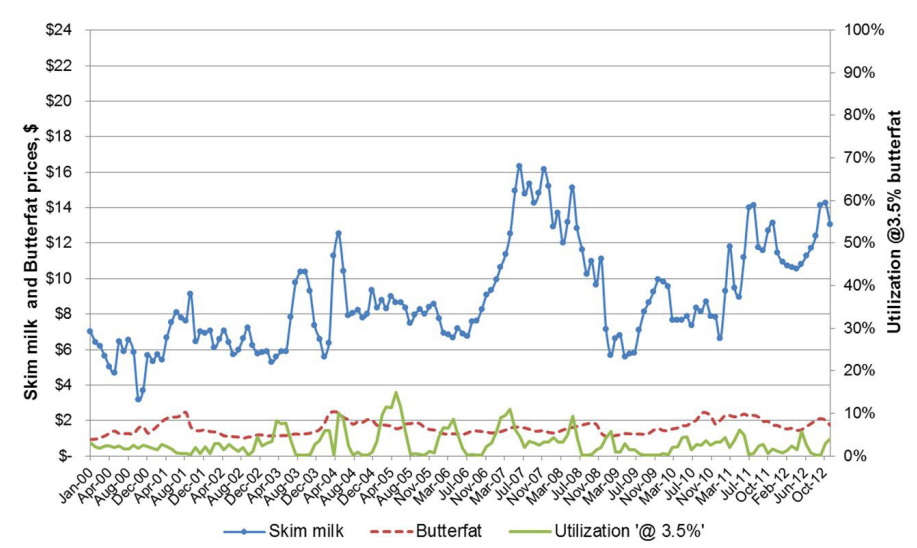

Figure 7. Federal Milk Marketing Order 6 (Florida) Class III prices and utilization at 3.5\% butterfat. Source: USDA Agricultural Marketing Service Dairy Programs, accessed January 2013, http://www. fmmatlanta.com.

The uniform price ( $\$ / \mathrm{cwt}$ ) is equal to the uniform skim milk price ( $\$ / \mathrm{cwt}$ ) multiplied by 0.965 plus 3.5 times the uniform butterfat price $(\$ / \mathrm{lb})$. The average utilization at $3.5 \%$ butterfat of each of the four classes during the last 12 years was $85.3 \%$ for Class I, 7.87\% for Class II, 2.95\% for Class III, and $3.76 \%$ for Class IV. Thus, the vast majority of the milk produced in Florida is used as fluid milk (Class I) primarily sold in Florida.

From January 2000 to December 2012, the Class I skim milk price (Figure 5) ranged from $\$ 9.91$ to $\$ 21.10 /$ cwt. Annual average prices were calculated from the monthly data. The lowest annual average skim price was $\$ 11.01 /$ cwt in 2002 and the highest skim price was $\$ 17.87 /$ cwt in 2008 . The skim milk price was relatively volatile over the 2000-2012 periods with large price swings. The Class I butterfat price ranged from $\$ 1.025$ to $\$ 2.504 / \mathrm{lbs}$ of butterfat; the lowest butterfat price was $\$ 1.213 / \mathrm{lbs}$ in 2000 , and the highest butterfat price was $\$ 2.203 /$ lbs of butterfat in 2011 . 
Class II skim milk prices (Figure 6) ranged monthly from $\$ 6.47$ to $\$ 17.74 / \mathrm{cwt}$. The lowest annual average skim price was $\$ 6.74 /$ cwt in 2003 , and the highest skim price was $\$ 13.67 /$ cwt in 2007. The Class II butterfat price ranged from $\$ 0.94$ to $\$ 2.51 /$ lbs of butterfat. The lowest butterfat price was $\$ 1.19 / \mathrm{lbs}$ in 2002 , and the highest butterfat price was $\$ 2.16 /$ lbs of butterfat in 2011 .

The monthly Class III skim prices (Figure 7) ranged from $\$ 3.17$ to $\$ 16.31 /$ cwt between January 2000 and December 2012. The lowest annual average Class III skim milk price was $\$ 5.55 / \mathrm{cwt}$ in 2000 , and the highest price was $\$ 13.37$ / cwt in 2007. The Class III butterfat price ranged from $\$ 0.94$ to $\$ 2.50 / \mathrm{lbs}$ of butterfat. The lowest price was $\$ 1.19 / \mathrm{lb}$ in 2002 , and the highest price was $\$ 2.15 /$ lbs of butterfat in 2011.

The monthly Class IV skim prices (Figure 8) ranged from $\$ 5.78$ to $\$ 16.97 / \mathrm{cwt}$. The lowest annual average price was $\$ 5.98 /$ cwt in 2003, and the highest price was $\$ 13.70 /$ cwt of skim milk in 2007. Class IV butterfat price ranged from $\$ 0.94$ to $\$ 2.50 / \mathrm{lbs}$ of butterfat. The lowest price was $\$ 1.19$ / lbs in 2002, and the highest price was $\$ 2.15 /$ lbs in 2011.

The monthly uniform milk prices at 3.5\% butterfat (Figure 9) ranged from $\$ 9.23$ to $\$ 20.56 /$ cwt. The lowest annual average uniform skim milk price was $\$ 10.67 /$ cwt in 2002 , and the highest price was $\$ 16.90 / \mathrm{cwt}$ in 2007 . The uniform butterfat price ranged from $\$ 0.97$ to $\$ 2.46 / \mathrm{lbs}$ of butterfat. The lowest price was $\$ 1.23 / \mathrm{lbs}$ in 2003 , and the highest price was $\$ 2.18 / \mathrm{lbs}$ of butterfat in 2011.

Dairy producers can negotiate higher prices for their milk from milk buyers. These higher prices are called over-order prices. The difference between uniform price and the over-order price is called over-order charge or over-order payment or premium. Table 4 shows over-order prices, uniform prices, and over-order charges from milk used in all classes in Florida from 2004 until present. Prices for 2012 are the average FMMO 6 prices from January to October.

In conclusion, the reported data show that milk produced per cow per year in Florida has constantly increased. After years of decline, the number of dairy cows has stabilized. Total milk production per year has been increasing slowly in recent years. All milk prices have been increasing but showed larger swings in the last 10 years. Milk produced in Florida is primarily used as fluid milk as shown by the percentage of utilization at $3.5 \%$ butterfat for Class I. As a result of the high Class I utilization, mailbox prices in Florida are higher than other FMMO areas.

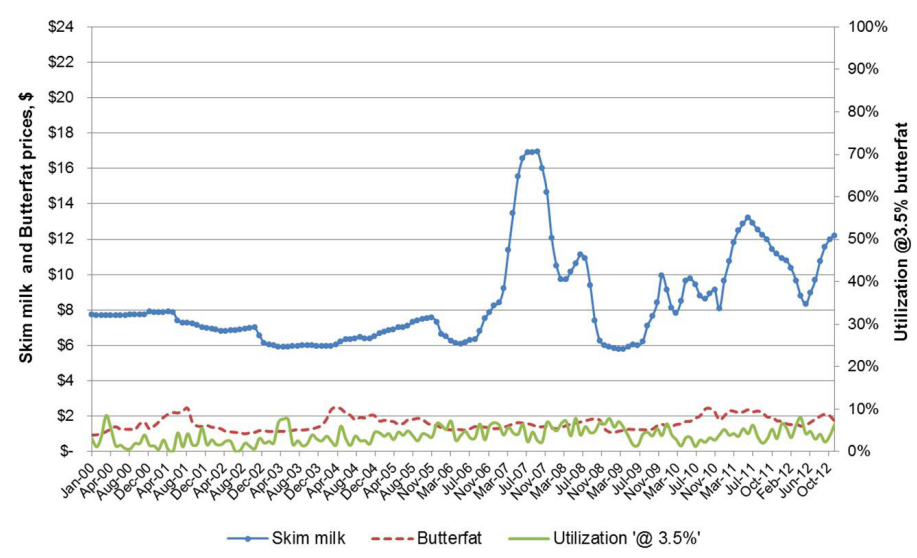

Figure 8. Federal Milk Marketing Order 6 (Florida) Class IV prices and utilization at 3.5\% butterfat. Source: USDA Agricultural Marketing Service Dairy Programs, accessed January 2013, http://www. fmmatlanta.com.

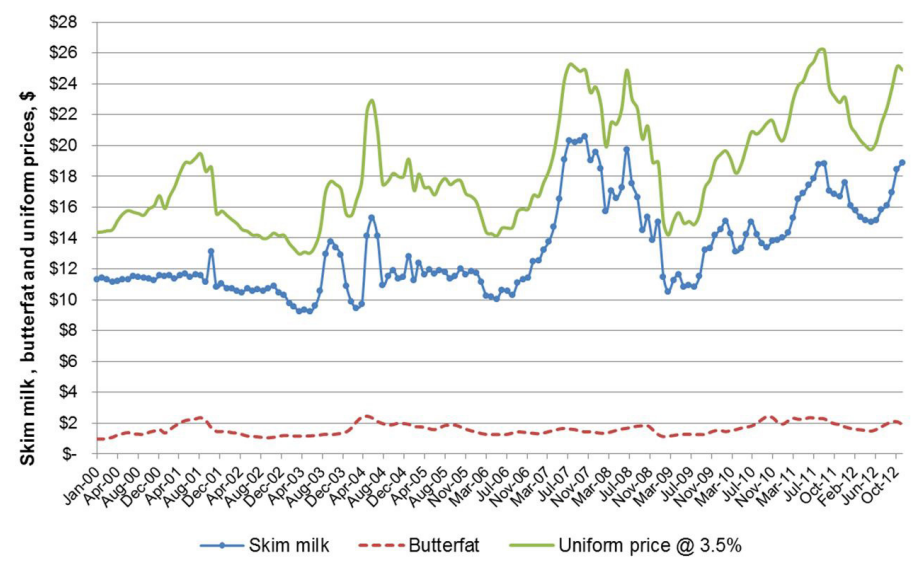

Figure 9. Federal Milk Marketing Order 6 (Florida) uniform prices at 3.5\% butterfat. Source: USDA Agricultural Marketing Service Dairy Programs, accessed January 2013, http://www.fmmatlanta.com. 
Table 4. Over-order prices, uniform prices, and over-order charge on milk used in all classes in Florida (2004 - 2012). ${ }^{1}$

\begin{tabular}{|c|c|c|c|}
\hline & Over-order price & Uniform price @3.5\% butterfat & Over-order charge \\
\hline Year & (\$/cwt) & (\$/cwt) & (\$/cwt) \\
\hline 2004 & 20.29 & 18.40 & 1.89 \\
\hline 2005 & 19.72 & 17.57 & 2.15 \\
\hline 2006 & 18.02 & 15.23 & 2.79 \\
\hline 2007 & 24.20 & 21.52 & 2.68 \\
\hline 2008 & 25.36 & 21.87 & 3.49 \\
\hline 2009 & 19.07 & 16.12 & 2.95 \\
\hline 2010 & 23.05 & 20.12 & 2.93 \\
\hline 2011 & 26.36 & 23.77 & 2.59 \\
\hline $2012^{2}$ & 23.82 & 21.30 & 2.52 \\
\hline \multicolumn{4}{|c|}{$\begin{array}{l}{ }^{1} \text { Federal Milk Marketing Orders establish minimum prices, known as uniform prices. Dairy producers can negotiate with milk buyers to sell milk } \\
\text { at higher prices, and these are called over-order prices. The difference between the uniform price and the over-order price is called over-order } \\
\text { charge or over-order payment. } \\
{ }^{2} \text { Prices for } 2012 \text { are the average from January through October. } \\
\text { Source: USDA Agricultural Marketing Service, accessed January } 2013 \text {, http://www.ams.usda.gov. }\end{array}$} \\
\hline
\end{tabular}

